\title{
Commentary 4 to the Manifesto for the Marine Social Sciences: the politics of research agendas
}

\author{
Joeri Scholtens ${ }^{1} \cdot$ Nathan Bennett ${ }^{2}$ \\ Published online: 3 July 2020 \\ (C) The Author(s) 2020
}

Researchers often formulate and propose research agendas, aiming to draw attention of fellow academics, funders, and other stakeholders to research topics and questions that they deem important. Since such agendas aim to coax students, researchers, and funders to prioritize attention for certain phenomena over others, they essentially constitute battles for attention, time, and funding. Thus, they should not be seen as merely technical exercises but rather as covert or overt efforts to influence the knowledge commons as well as the process of political prioritization. This comment aims to put the present "Manifesto for the Marine Social Sciences" in the context of a wealth of agendas that have been proposed over the past two decades.

A first category of such research agendas focuses on subfields of the marine realm resulting in the identification of research gaps and priorities. Examples include agendas for fisheries (Symes 2006; Urquhart et al. 2011), marine protected areas (Charles and Wilson 2009; Christie et al. 2003), large-scale marine protected areas (Gruby et al. 2016), ocean energy (Wright et al. 2016), marine renewable energy (Kerr et al. 2014), the blue economy (McKinley et al. 2018), and ocean plastics (Mendenhall 2018). Others have been more generic, listing key topics and priorities for future research across all marine and coastal policy realms (Rees et al. 2013), or identifying the contributions that the social sciences can make to guide the governance of peopled seas (Bennett 2019). These efforts tend to be presented as fairly apolitical, emphasizing the importance of

Joeri Scholtens

j.scholtens@uva.nl

Nathan Bennett

nathan.bennett@ubc.ca

1 Amsterdam Institute for Social Science Research, University of Amsterdam, Amsterdam, The Netherlands

2 Institute for the Oceans and Fisheries, University of British Columbia, Vancouver, Canada addressing the "human dimensions," without radically confronting a status quo. They seek to influence or improve current research and policy, but do not question the system at large. One might view these as "reformist" research agendas.

Then, there are those agendas that call upon using social science to take a stance with regard to achieving more controversial ends - such as more socially equitable, environmentally just, culturally appropriate, or politically inclusive ocean governance or marine conservation. These tend to be more poignant, punchy and political, more critical, and confrontational about what is wrong with current practices, less shy about pointing fingers towards adversaries and more explicit in their attempts to reorient the focus of marine scientists. For example, Bavinck et al. (2018) call upon marine social scientists to look into the empirical reality of fisheries as a domain of struggle, instead of just a domain of management; Bennett (2018) issues a call to action for researchers, policymakers, practitioners, and funders to pay more explicit attention to social justice issues; Poe et al. (2014) urge that ignoring cultural considerations risks producing unaccounted negative social impacts for communities; and Winder and Le Heron (2017) encourage an informed and critical engagement with the blue economy. These "activist" research agendas call for a more engaged science that better represents marginal voices, interests, and viewpoints in ocean governance.

The present Manifesto arguably holds the middle ground between both categories. Significant is the very framing of the research agenda in terms of a Manifesto by and for a collective of social scientists, thus implicitly recognizing its inherent political character. While it does not quite identify a specter or call upon scientists to mobilize for radical change, it clearly follows from a discontent with the current praxis and priorities of marine policy and science. It goes beyond merely dictating what research gaps social scientists should study, to also call for a transformation in terms of how they practice their research, whom they should listen to and engage with, and how they should advocate for change. Many of the Manifesto's points express concern with injustice and 
vulnerability of underrepresented groups and voices (e.g., coastal communities, women, small-scale fishers). While some may argue that by doing so, the Manifesto unduly mixes up science and politics, others will say it is not political enough, as it does not explicitly point fingers towards the most obvious political or economic drivers of these trends.

Science is the quest for knowledge and knowledge is power. If research agendas guide what research topics should receive funding and attention, and suggest what is worth knowing and what knowledge should be the basis of decisions, then the construction of research agendas is an inherently political activity. Research agendas that present themselves as apolitical, hiding behind a veil of scientific or technical objectivity, may in fact be quite political by implicitly legitimizing and reproducing a status quo.

Since the status quo represents some interests better than others, it is perhaps not surprising that marine social sciences that critically engage with poverty and well-being, political ecology, rights, culture, justice, access, and social struggles tend to receive less funding and attention. Yet, the lived realities of small-scale fishers, Indigenous peoples, and coastal communities should matter and be considered in ocean governance. Thus, we end by reiterating that marine social science research agendas are inherently political, and therefore ought to do so overtly, which will help to advance the needed transformation of ocean governance in a manner that does not further marginalize and reproduce injustices for coastal peoples.

Open Access This article is licensed under a Creative Commons Attribution 4.0 International License, which permits use, sharing, adaptation, distribution and reproduction in any medium or format, as long as you give appropriate credit to the original author(s) and the source, provide a link to the Creative Commons licence, and indicate if changes were made. The images or other third party material in this article are included in the article's Creative Commons licence, unless indicated otherwise in a credit line to the material. If material is not included in the article's Creative Commons licence and your intended use is not permitted by statutory regulation or exceeds the permitted use, you will need to obtain permission directly from the copyright holder. To view a copy of this licence, visit http://creativecommons.org/licenses/by/4.0/.

\section{References}

Bavinck, M., S. Jentoft, and J. Scholtens. 2018. Fisheries as social struggle: A reinvigorated social science research agenda. Marine Policy 94: 46-52.
Bennett, N.J. 2018. Navigating a just and inclusive path towards sustainable oceans. Marine Policy 97: 139-146. https://doi.org/10.1016/j. marpol.2018.06.001.

Bennett, N.J. 2019. Marine social science for the peopled seas. Coastal Management 47 (2): 244-252.

Charles, A., and L. Wilson. 2009. Human dimensions of Marine Protected Areas. ICES Journal of Marine Science: Journal Du Conseil 66 (1): 6-15.

Christie, P., McCay, B. J., Miller, M. L., Lowe, C., White, A. T., Stoffle, R. W., ... \& Suman, D. O. (2003). Toward developing a complete understanding: A social science research agenda for marine protected areas. Fisheries, 28(12), 22-26.

Gruby, R.L., N.J. Gray, L.M. Campbell, and L. Acton. 2016. Toward a social science research agenda for large marine protected areas. Conservation Letters 9 (3): 153-163.

Kerr, S., Watts, L., Colton, J., Conway, F., Hull, A., Johnson, K., ... \& Potts, T. (2014). Establishing an agenda for social studies research in marine renewable energy. Energy Policy, 67, 694-702.

McKinley, E., O. Aller-Rojas, C. Hattam, C. Germond-Duret, I.V.S. Martín, C.R. Hopkins, H. Aponte, and T. Potts. 2018. Charting the course for a blue economy in Peru: A research agenda, 1-23. Development and Sustainability: Environment. https://doi.org/10. 1007/s10668-018-0133-z.

Mendenhall, E. 2018. Oceans of plastic: A research agenda to propel policy development. Marine Policy 96: 291-298.

Poe, M.R., K.C. Norman, and P.S. Levin. 2014. Cultural Dimensions of Socioecological Systems: Key Connections and Guiding Principles for Conservation in Coastal Environments: Cultural dimensions of coastal conservation. Conservation Letters 7 (3): 166-175. https:// doi.org/10.1111/conl.12068.

Rees, S., Fletcher, S., Glegg, G., Marshall, C., Rodwell, L., Jefferson, R., ... \& Brutto, D. (2013). Priority questions to shape the marine and coastal policy research agenda in the United Kingdom. Marine Policy, 38, 531-537.

Symes, D. 2006. Fisheries governance: A coming of age for fisheries social science? Fisheries Research 81 (2-3): 113-117. https://doi. org/10.1016/j.fishres.2006.06.015.

Urquhart, J., T. Acott, M. Reed, and P. Courtney. 2011. Setting an agenda for social science research in fisheries policy in Northern Europe. Fisheries Research 108 (2-3): 240-247.

Winder, G.M., and R. Le Heron. 2017. Assembling a Blue Economy moment? Geographic engagement with globalizing biologicaleconomic relations in multi-use marine environments. Dialogues in Human Geography 7 (1): 3-26. https://doi.org/10.1177/ 2043820617691643.

Wright, G., A.M. O’Hagan, J. de Groot, Y. Leroy, N. Soininen, R. Salcido, M.A. Castelos, S. Jude, J. Rochette, and S. Kerr. 2016. Establishing a legal research agenda for ocean energy. Marine Policy 63: 126-134.

Publisher's note Springer Nature remains neutral with regard to jurisdictional claims in published maps and institutional affiliations. 